\title{
TES INVENTORY PERSONAL SURVEY (TIPES) SEBAGAI REKOMENDASI PEMILIHAN JURUSAN SEKOLAH MENENGAH KEJURUAN
}

\author{
Agus Aan Jiwa Permana ${ }^{1)}$ Ni Wayan Marti ${ }^{2)}$ Kadek Suranata ${ }^{3)}$ \\ D3 Manajemen Informatika, Fakultas Teknik dan Kejuruan ${ }^{1)}{ }^{2)}$ \\ Pendidikan S1 Bimbingan Konseling, Fakultas Ilmu Pendidikan ${ }^{3)}$ \\ Undiksha, Singaraja, Bali \\ agus.aan@undiksha.ac.id wayan.marti@undiksha.ac.id sura@konselor.org
}

\begin{abstract}
In developing superior human resources, it takes a long time, is focused, and requires support from all components of society. We can see developing and developed countries having reliable human resources both in the fields of technology, agriculture, maritime affairs and tourism. The current big challenge to support the development of the creative economy is closely related to increasing the quantity and quality of vocational education (vocational) to be able to compete globally. The Specialization Test used during the selection of new students can provide an alternative selection of majors to new students in accordance with the competencies they have, so that the system issues a choice of department recommendations in accordance with their competencies. This is the basis for implementing the system as an initial filter for selection of students having competencies with appropriate interests then through the education process to face the fourth industrial revolution (i4.0). With initial selection through the TIPES system, expectations are in line with the 2010-2014 Ministry of Education and Culture RENSTRA, namely $70 \%$ of SMK graduates work in the graduation year and all SMKs providing entrepreneurship development coaching services can be realized.
\end{abstract}

Keywords: superior human resources, creative economy, global competing vocational, majors selection recommendations

\begin{abstract}
ABSTRAK
Dalam mengembangkan SDM yang unggul memerlukan waktu yang cukup lama, terfokus, serta memerlukan dukungan dari seluruh komponen masyarakat. Kita bisa lihat negara yang sedang berkembang dan maju memiliki SDM yang handal baik di bidang teknologi, pertanian, kelautan, dan pariwisata. Tantangan besar saat ini untuk menunjang pengembangan ekonomi kreatif sangat berhubungan dengan meningkatkan kuantitas dan kualitas pendidikan kejuruan (vokasi) untuk mampu bersaing secara global. Test Peminatan yang digunakan saat seleksi siswa baru dapat memberikan alternatif pemilihan jurusan kepada siswa baru sesuai dengan kompetensi yang mereka punya, sehingga sistem mengeluarkan rekomendasi pilihan jurusan sesuai dengan kompetensinya. Hal inilah yang menjadi dasar untuk mengimplementasikan sistem sebagai saringan awal untuk seleksi siswa memiliki kompetensi dengan minat yang sesuai kemudian melalui proses pendidikan untuk menghadapi revolusi industri keempat (i4.0). Dengan seleksi awal melalui sistem TIPES, maka harapan sesuai dengan RENSTRA Kemendikbud 2010 - 2014 yaitu 70\% lulusan SMK bekerja pada tahun kelulusan dan seluruh SMK menyediakan layanan pembinaan pengembangan kewirausahaan dapat terwujud.
\end{abstract}

Kata Kunci : SDM handal, Ekonomi kreatif, Vokasi bersaing global, Rekomendasi pemilihan jurusan 


\section{PENDAHULUAN}

Tujuan pendidikan nasional adalah mengembangkan potensi peserta didik agar menjadi manusia yang beriman dan bertakwa kepada Tuhan Yang Maha Esa, berakhlak mulia, sehat, berilmu, capak, kreatif, mandiri, dan menjadi warga negara yang demokratis serta bertanggu jawab (Undang-undang No. 20 Tahun 2003). Kemudian didukung dengan (RENSTRA Kemendikbud $2010 \quad-\quad 2014)$ yang menekankan upaya peningkatan kualitas sumber daya manusia (SDM) termasuk pengembangan kemampuan ilmu dan teknologi serta penguatan daya saing perekonomian.

Hal ini menjadi tugas kita semua untuk dapat menyukseskan program pemerintah bahwa sistem pendidikan di Indonesia harus diperbaiki. Proses pembangunan SDM membutuhkan waktu yang cukup lama, fokus, dan memerlukan dukungan dari seluruh komponen masyarakat. Kita bisa lihat negara yang sedang berkembang dan maju memiliki SDM yang handal baik di bidang teknologi, pertanian, kelautan, dan pariwisata. Jepang adalah salah satu negara tetangga Indonesia yang maju di segala sektor sehingga perekonomiannya sangat bagus. SDM yang unggul di masa depan adalah yang memiliki karakter kuat dan kreatif dalam menghadapi segala persoalan dalam rangka menghadapi persaingan kerja yang semakin ketat. Semua bangsa di dunia sepakat akan hal ini yaitu mencetak SDM unggul melalui pendidikan (Jampel, 2017).

Tantangan besar saat ini untuk menunjang pengembangan ekonomi kreatif sangat berhubungan dengan meningkatkan kuantitas dan kualitas pendidikan kejuruan (vokasi) untuk mampu bersaing secara global. Pendidikan kejuruan dikatakan memiliki sebuah misi khusus untuk mendorong peserta didik lebih berdaya saing dalam bidang pekerjaan untuk mencapai tujuan karir untuk kelayakan hidup serta meningkatkan keterampilan dan produktivitasnya untuk menjadikan pertumbuhan ekonimi suatu negara lebih kuat dalam persaingan internasional (Hanafi, 2014:3). Namun terkait dengan beberapa hasil riset di beberapa negara menyatakan bahwa lulusan pendidikan vokasi tidak lebih baik jika jika dibandingkan dengan pendidikan akademik (Hanafi, 2014:3).

Hal yang sama disampaikan Pratiwi (2013) yang mengatakan bahwa lulusan SMK ditempa menjadi SDM yang siap pakai dalam arti setelah lulus dapat menerapkan ilmu di dunia kerja. Namun kebanyakan sekolah SMK tidak menghasilkan lulusan dengan pengetahuan dan keahlian (skill dan knowledge) yang dibutuhkan dunia industri, sehingga perlu mengimplementasikan sistem manajemen mutu (SMM) ISO 9001:2008.

Pada beberapa negara maju seperti Singapura dan Taiwan, pihak kampus sudah menjalin kerjasama dengan dunia industri sehingga para lulusan sekolah vokasi nantinya dapat langsung bekerja pada tempat mereka magang. Presiden Jokowi juga ingin melakukan reorientasi pendidikan dan pelatihan vokasi ke arah demand driven dengan sertifikasi sesuai dengan permintaan dunia industri (Humas, 2016).

Data BPS mencatat tahun 2014 lulusan SMK yang menganggur mencapai 813.776 jiwa $(11,24 \%)$ dari jumlah total pengangguran terbuka di Indonesia yakni 7,24 juta jiwa. Tahun 2015 bahkan mengalami peningkatan sebanyak 300.000 jiwa dari 7,45 juta jiwa pengangguran terbuka. Lebih parah lagi bahwa pengangguran paling besar didominasi oleh masyarakat dengan latar belakang pendidikan SMK sebesar 9.05. Tingginya angka pengangguran lulusan SMK adalah sebuah persoalan besar yang disebabkan kemampuan perekonomian dalam menyediakan lapangan kerja dan sistem pendidikan yang gagal dalam menyediakan lulusan siap kerja, permasalah mendasar adalah kompetensi dan keahlian lulusan SMK yang kurang memenuhi harapan dunia industri (Sunardi, dkk., 2016).

Berdasarkan wawancara pada saat mencari data, kepala sekolah SMK 3 Singaraja mengatakan bahwa dalam pemilihan jurusan, calon siswa memilih jurusan dengan memilih jurusan yang sesuai dengan keinginan mereka. Jurusan yang favorit disana adalah yang berbasis komputer yaitu multimedia(MM) dan teknik komputer jaringan (TKJ). Padahal terdapat 10 jurusan pada sekolah tersebut, namun minat siswa saat ini lebih banyak ke jurusan yang berbasis komputer. Hal ini berdampak menumpuknya siswa yang memilih jurusan favorit tanpa tahu apakah mereka memiliki kemampuan untuk mengikuti mata pelajaran pada jurusan yang dipilih. Setelah melalui proses diskusi maka dengan sistem TIPES yang digunakan saat seleksi siswa baru dapat memberikan alternatif pemilihan jurusan kepada siswa baru sesuai dengan kompetensi yang mereka punya, sehingga sistem 
mengeluarkan rekomendasi pilihan jurusan sesuai dengan kompetensinya. Hal ini akan memberikan alternatif kepada siswa untuk memilih beberapa jurusan yang sesuai dengan minat mereka. Siswa dapat melakukan konsultasi dengan konselor sekolah (Guru Bimbingan dan Konseling) untuk memberikan penjelasan dan pertimbangan tentang jurusan yang akan dipilih siswa.

Dengan seleksi awal melalui sistem TIPES, maka harapan sesuai dengan RENSTRA Kemendikbud 2010 - 2014 yaitu $70 \%$ lulusan SMK bekerja pada tahun kelulusan dan seluruh SMK menyediakan layanan pembinaan pengembangan kewirausahaan dapat terwujud. Bennet (2006, dalam Sunardi,dkk. 2016) menyebutkan lulusan harus memiliki kemampuan akademik, kemampuan keterampilan, dan kemampuan emploabilitas yang seimbang. Emploabilitas adalah kemampuan seseorang untuk menangani tugas-tugas yang berbeda dimana seorang tenaga kerja memiliki keterampilan sosial termasuk keterampilan dasar (baca, tulis, hitung), keterampilan interpersonal termasuk komunikasi dan bekerja dalam tim, dan atribut diri yaitu kemampuan belajar untuk menghadapi perubahan yang terjadi di masyarakat (Hanafi, 2012). Dalam menunjang pengembangan program keahlian SMK yang relevan dengan kebutuhan industri, maka pengembangan kompetensi inilah yang menjadi ujung tombak menciptakan link and match SMK dengan dunia industri (Jatmoko, 2013).

Hal inilah yang menjadi dasar untuk mengimplementasikan sistem TIPES sebagai saringan awal untuk seleksi siswa memiliki kompetensi dengan minat yang sesuai kemudian melalui proses pendidikan untuk menghadapi revolusi industri keempat (i4.0). Revolusi ini mempunyai ciri teknologi yang menyatu dengan masyarakat dan tubuh manusia seperti robotik, komputasi quantum, bioteknologi, 3D printing, otomasi kendaraan, internet, sistem virtual. Kondisi ini akan mempengaruhi kinerja pendidikan vokasi dalam menyiapkan lulusannya untuk bekerja khususnya perubahan kurikulum, penyesuaian perangkat pembelajaran, dan kesiapan para pendidiknya (Triyono, 2017).

Pengembangan TIPES Tahap I mengalami beberapa kendala terkait dengan modul-modul dalam sistem yang memerlukan penyempurnaan seperti tampilan yang lebih user friendly sehingga interaksi dengan user lebih nyaman. TIPES Tahap I sementara dapat diakses secara online pada alamat http://tipesundiksha.com. Pengembangan sistem secara offline sudah dapat jalan, namun sekali lagi apabila online beberapa kendala dapat saja muncul seperti error beberapa modul yang belum dapat diakses.

Pengembangan Tapah II lebih difokuskan lagi terhadap konten pada sistem sehingga siswa dapat mengakses secara lebih nyaman dengan uji coba yang lebih luas lagi. Penambahan data juga perlu dilakukan untuk meningkatkan jumlah rekomendasi yang dihasilkan sistem pada beberapa jurusan vokasi yang sesuai dengan minat siswa pada sekolah yang diinginkan khususya di Bali. Perlu dikembangkan sebuah sistem TIPES Tahap II yang responsif, reliability, dan ketepatan dalam memberikan rekomendasi. Sehingga target utama dalam penelitian ini TIPES dapat terdaftar pada HAKI (Hak Atas Kekayaan Intelektual).

\section{TINJAUAN PUSTAKA}

\section{Penelitian Terkait}

Dalam memfokuskan penelitian ini, telah diperoleh beberapa sumber yang terkait dengan penelitian yang sedang dilaksanakan seperti Tabel 1.

Tabel 1. State the arts

\begin{tabular}{|c|c|c|}
\hline No. & $\begin{array}{l}\begin{array}{l}\text { Penulis } \\
\text { (Tahun) }\end{array} \\
\end{array}$ & Ruang Lingkup \\
\hline 1 & $\begin{array}{l}\text { Suranata } \\
(2009)\end{array}$ & $\begin{array}{l}\text { Penelitian ini berfokus } \\
\text { pada penyesuaian antara } \\
\text { tipe kepribadian dengan } \\
\text { model lingkungan. } \\
\text { Belum ada aplikasi }\end{array}$ \\
\hline 2 & $\begin{array}{l}\text { Permana } \\
\text { (2013) }\end{array}$ & $\begin{array}{l}\text { Penelitian ini berfokus } \\
\text { pada penentuan } \\
\text { kelayakan mahasiswa } \\
\text { dalam mengikuti } \\
\text { program magang serta } \\
\text { dapat } \\
\text { merekomendasikan } \\
\text { tempat magang sesuai } \\
\text { dengan kompetensi } \\
\text { Belum dikembangkan } \\
\text { tes online }\end{array}$ \\
\hline 3 & $\begin{array}{l}\text { Asmara dan } \\
\text { Haryanto } \\
\text { (2015) }\end{array}$ & $\begin{array}{l}\text { Penelitian ini berfokus } \\
\text { pada Proses peminatan } \\
\text { bertujuan untuk } \\
\text { menempatkan siswa } \\
\text { sesuai bidang keahlian } \\
\text { yang tepat }\end{array}$ \\
\hline
\end{tabular}




\begin{tabular}{|l|l|l|}
\hline & & $\begin{array}{l}\text { Belum dikembangkan } \\
\text { tes online }\end{array}$ \\
\hline 4 & $\begin{array}{l}\text { Deha dan } \\
\text { Mulyana } \\
(2010)\end{array}$ & $\begin{array}{l}\text { Penelitian ini berfokus } \\
\text { pada evaluasi berbasis } \\
\text { kompetensi. }\end{array}$ \\
& $\begin{array}{l}\text { Belum dikembangkan } \\
\text { tes online }\end{array}$ \\
\hline
\end{tabular}

\section{Pendidikan Vokasi}

Saat ini pendidikan vokasi mendapat perhatian yang serius dari pemerintah terbukti dengan dikeluarkannya UU No. 12, Tahun 2012 tentang pendidikan tinggi. Program Studi adalah kesatuan kegiatan Pendidikan dan pembelajaran yang memiliki kurikulum dan metode pembelajaran tertentu dalam satu jenis pendidikan akademik, pendidikan profesi, dan/atau pendidikan vokasi (UU No. 12, Tahun 2012). Pendidikan vokasi merupakan pendidikan yang mengarahkan mahasiswa untuk mengembangkan keahlian terapan, beradaptasi pada bidang pekerjaan tertentu dan dapat menciptakan peluang kerja. Pendidikan vokasi menganut sistem terbuka (multi-entry-exit system) dan multimakna (berorientasi pada pembudayaan, pemberdayaan, pembentukan watak, dan kepribadian, serta berbagai kecakapan hidup (life skill) (Universitas Brawijaya, 2016)

Bahkan di luar negeri Pemetintah Italia sudah dalam rangka mengimplementasikan Agenda Digitalnya telah merombak sistem pendidikan di negara tersebut dimana semua anak memiliki hak untuk mengikuti pendidikan dan pelatihan setidaknya 12 Tahun, berlaku bagi siswa berumur 15 tahun atau lebih yang dapat diterima untuk magang di perusahaan karena sudah menandatangai kesepakatan dengan MIUR (Departemen Tenaga Kerja) (Nazzaro, 2016)

Berdasarkan paparan vokasi diatas, dalam sistem pendidikan vokasi terdapat perbedaan dengan sistem pendidikan di SMU karena peserta didik diarahkan untuk menjadi tenaga kerja yang siap pakai dan siap bersaing di level industri. Industri sangat membutuhkan tenaga kerja yang memiliki ketrampilan untuk bekerja pada bidang tertentu misalkan pada pariwisata, komputer, perikanan, maritim, perkapalan, pertanian, perkebunan, farmasi, tata boga, tata busana, otomotif, perhotelan, akuntansi, administrasi perkantoran, perbankan, travel, dan pemasaran. Sehingga peran SMK dan sekolah sederajat serta perguruan tinggi harus menjalin kerjasama dengan pihak pemerintah dan dunia industri untuk menghasilkan tenaga kerja yang demand driven seperti harapan Pak Presiden Jokowi.

HC Indonesia (2014) menulis sebuah artikel yang mengatakan bahwa terdapat tiga keistimewaan pada pendidikan kejuruan (vokasi) antara lain :

1. Lebih Praktikal : Jika Anda merasa menghadiri kelas kuliah membosankan, tidak suka mengerjakan tugas dan dinilai dengan cara ujian, Anda boleh mempertimbangkan pendidikan vokasi. Pendidikan vokasi benar-benar melatih keahlian praktikal, sehingga tentu saja lebih banyak praktek daripada teori.

2. Banyak pilihan institusi : Berbeda dengan pendidikan gelar sarjana dan sebagainya, pendidikan vokasi ditawarkan lebih banyak institusi, baik itu universitas, kolese, politeknik, pusat pelatihan ataupun institusi-institusi lainnya yang berspesialisasi menyelenggarakan program pendidikan vokasi

3. Beragam pilihan program : Pendidikan vokasi cocok bagi mereka yang sudah jelas dan yakin dengan apa yang ingin mereka kejar sebagai karir masa depan. Banyak sekali bidang yang tersedia mulai dari pariwisata dan perhotelan, manajemen retail, pengembangan software, desain interior, teknik otomotif, penata rambut hingga kuliner.

\section{Tes Inventory Personal Survey (TIPES)}

Sebelum manusia mengenal alat pengukuran yang saat ini dikenal dengan inventori kepribadian, usaha mendapatkan karakteristik kepribadian seseorang telah ada dengan cara seperti melihat garis tangan, raut muka, tanggal/hari kelahiran, dan usaha lainnya (Suranata, 2009).

Pengukuran kepribadian merupakan hal yang dianggap penting dalam pengetahuan tentang karier semenjak 75 tahun yang lalu (1918-an), meskipun banyak dipusatkan pada kepribadian yang abnormal, hal ini juga telah dilakukan pada kepribadian normal, khususnya untuk membantu individu melakukan seleksi dalam menentukan pilihan terhadap pekerjaan serta jabatan (Suranata, 2009; Nauta, 2010).

Holland (1985) menggolongkan orang dengan kemiripan dalam enam tipe kepribadian yaitu : realistic, investigative, artistic, social, enterprising, dan conventional (RIASEC). Kesesuaian 
seseorang dan lingkungan dapat mengarahkan seseorang supaya dapat memprediksi dan memahami pengetahuan tentang tipe kepribadian dan model lingkungan. Hal ini akan sangat bermanfaat untuk pilihan pekerjaan, stabilitas vocasional dan prestasi, pilihan pendidikan dan prestasi, kompetensi individu, perilaku sosial, dan untuk mempengaruhi kepekaan seseorang.

Tes Inventory personal survey (TIPES) online yang dikembangkan dalam penelitian ini diadaptasi dari inventori Self Direct Search Inventory (SDS) yang yang diilhami dari teori kepribadian dan karir Holland (1975). SDS adalah jenis inventori yang dikembangkan Holland melalui adaptasi dan penyempurnaan Vocational Preference Inventory (VPI) yang dibuat tahun 1958. SDS sudah mengalami revisi sebanyak tiga kali dan terakhir tahun 2001, dan telah digunakan dan diadaptasi lebih dari 20 bangsa di dunia dengan versi lebih dari 15 bahasa, dan telah terbukti melalui berbagai penelitian dalam mengukur tipe kepribadian dan memberikan prediksi tentang karier yang sesuai bagi siswa dan mahasiswa serta bagi mereka yang sudah berada dalam dunia kerja (Suranata, 2009; Nauta, 2010).

Tes Inventory personal survey (TIPES) yang dikembangkan ini terdiri dari enam dimensi, yang dikenal dengan RIASEC, yaitu dimensi: Realistik, Investigatif, Artistik, Sosial, Enterprising, dan Konvensional. Masing-masing dimensi tersebut akan diperbandingkan kepada pengisi melalui empat indikator yaitu : (1) minat dan keterlibatan dalam suatu aktifitas, (2) persepsi diri terhadap kemampuan melakukan suatu bidang/keahlian, (3) minat dan ketertarikan terhadap bidang pekerjaan atau jabatan tertentu, (4) penilaian diri untuk dapat mengerjakan bidang-bidang keahlian tertentu.

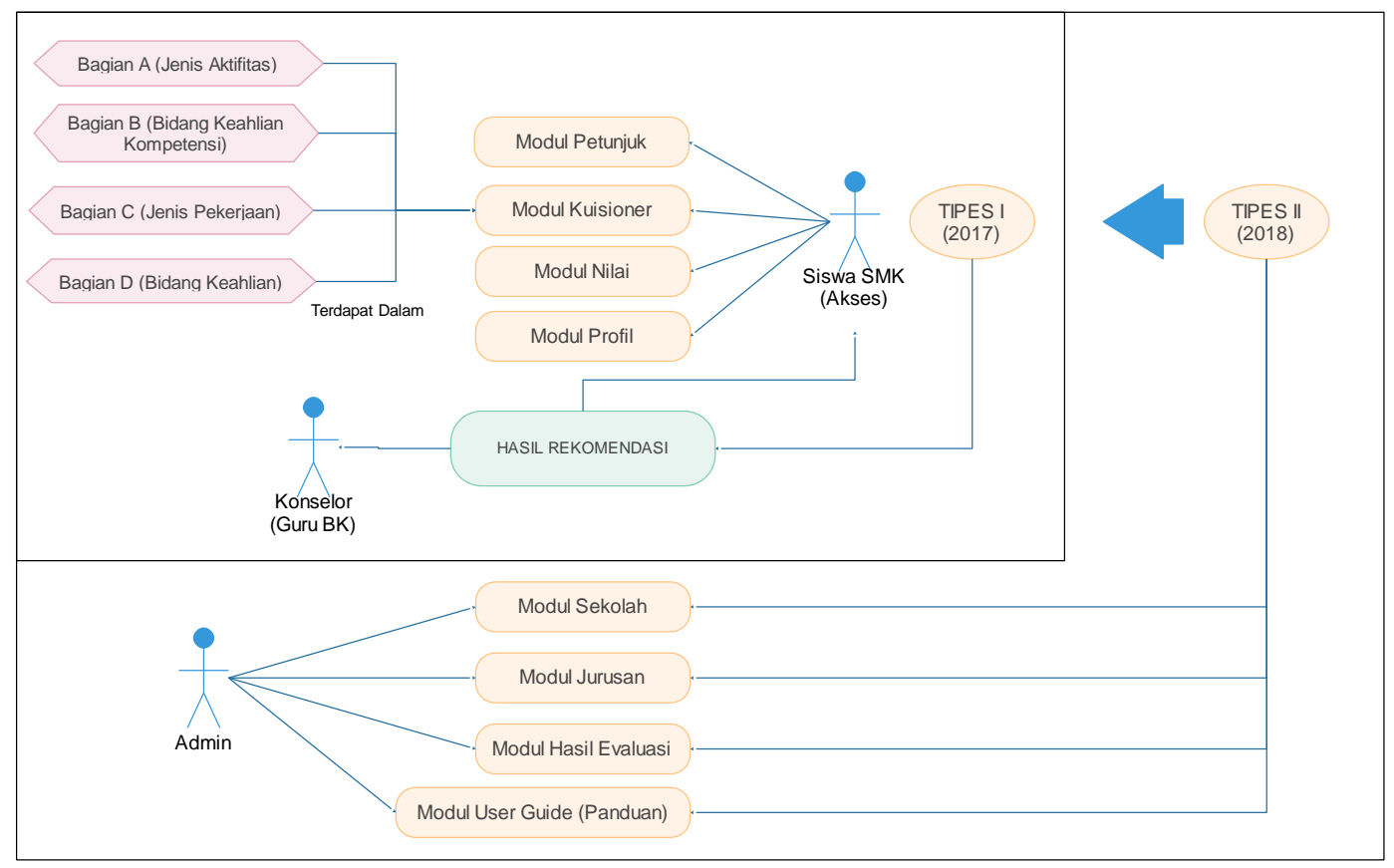

Gambar 2. Road Maps Penelitian Tahap I dan II

$$
C=\{3(c 1)+2(c 2)+1(c 3)\}
$$

Keterangan :

$$
\begin{aligned}
& \mathrm{C}=\text { Conggruency Scores atau skor kesesuaian } \\
& \mathrm{c1}=\text { skor kesesuaian digit pertama } \\
& \mathrm{c} 2=\text { skor kesesuaian digit kedua } \\
& \mathrm{c} 3=\text { skor kesesuaian digit ketiga }
\end{aligned}
$$




\section{Prosedur Analisis Data}

Terdapat beberapa jenis metode analisis data yang digunakan dalam penelitian di tahap pertama ini. (1) Analisis data berkaitan dengan identifikasi model tipe kepribadian yang berkesesuaian dengan bidang-bidang vokasi (jurusan) di SMK berdasarkan TIPES serta keterkaitannya dengan prestasi siswa menggunakan prosedur exploratory dan comfirmatory factor analysis (EFA dan CFA) melalui Program SPSS V. 22 dan Amos V. 21; (2) analisis data terkait dengan uji validitas teoretik rancangan model dilakukan dengan menggunakan metode analisis Gregory diperluas tiga Judges (Gregory, 2000), aspek-aspek yang menjadi penilaian dari rancangan model yang diuji (website dan Panduan) adalah meliputi (a) ketepatan, (b) kegunaan, (c) kemenarikan, (d) kelayakan, (e) kejelasan serta (f) aspek legal dan etik (Join Comitee, 1982); dan (3) analisis data terkait dengan uji implementasi sistem dalam skala kecil (terbatas) dilakukan dengan formulasi congruency between personality type and environmental model yang diadaptasi dari Miller, dkk (2004: 2) seperti persamaan 1 .

\section{Prosedur Pengembangan Sistem}

Pengembangan sistem TIPES tahap I adalah implementasi program yang terdiri dari empat modul yaitu : modul petunjuk, kuisioner, nilai, dan modul profil dari peserta yang mengikuti tes. Pada modul kuisioner memiliki empat bagian yaitu jenis aktifitas, keahlian kompetensi, jenis pekerjaan, dan bidang keahlian. Setelah siswa mengikuti tes, maka akan diberikan rekomendasi ke jurusan yang sesuai dengan kompetensinya. Siswa juga dapat melakukan konsultasi dengan konselor yang difasilitasi pihak sekolah untuk meyakinkan pilihan mereka Seperti Gambar 2.

Pada tahap II penelitian difokuskan pada penyepurnaan keempat modul sistem dalam versi online. Kemudian ditambah dengan penambahan beberapa data pada modul sekolah, jurusan, hasil evaluasi, serta membuat buku panduan penggunaan sistem untuk konselor yaitu guru BK serta siswa yang menggunakannya. Dengan interface yang responsif, serta data yang reliable karena diuji dalam ruang lingkup luas untuk jurusan vokasi yang ada di Bali. Adapun road maps penelitiannya adalah seperti Gambar 2.

\section{HASIL DAN PEMBAHASAN}

Dalam mempersiapkan sumber daya manusia unggul menuju industri 4.0 sekolah vokasi dapat melakukan hal penting seperti perubahan kurikulum, bekerja sama dengan industri dan institusi, tes peminatan, serta proses belajar yang benar. Melalui aplikasi tes peminatan, dapat dilakukan saat proses seleksi mahasiswa baru, untuk memberikan rekomendasi kepada siswa, orang tua, maupun sekolah untuk mengambil keputusan apakah potensi siswa cocok dengan bidang keahlian yang diminati. Tentu siswa selama ini sangat berhak memilih minat yang diinginkan, namun paling tidak sekolah sudah mempunyai standar dalam proses peminatan untuk siswanya. Sehingga peran guru yaitu wali kelas dan konselor (guru bimbingan konseling) dapat memaksimalkan potensi siswa yang mengambil minat yang kurang sesuai dengan potensinya. Sehingga siswa dapat mengikuti proses belajar dengan baik dan dapat lulus dan menguasi kompetensi.

Tes peminatan adalah salah satu cara untuk menstandarkan prosedur dalam menentukan minat siswa sehingga siswa memiliki gambaran minat apa yang sesuai dengan potensi yang dia miliki. Melalui hasil ujicoba aplikasi terhadap 10 responden menghasilkan tanggapan untuk beberapa kriteria

Ketepatan judul dengan content (85\%), Kejelasan informasi pada sistem (75\%), Kejelasan petunjuk yang ada pada sistem (93\%), Kesesuaian content dalam sistem(78\%), Kejelasan Navigasi Menu (75\%), Kemudahan akses sistem (93\%), Ketepatan Pengembangan sistem (73\%), Kejelasan Hasil tes (68\%) sehingga menghasilkan nilai rata-rata dalam pengujian sebesar $80 \%$ yang berarti sistem sudah dapat memuaskan pengguna akhir.

Berdasarkan survey yang dilakukan di lapangan dengan responden 178 Orang di beberapa kabupaten yang ada pada Provinsi Bali, sebanyak $57 \%$ siswa memiliki potensi yang sesuai dengan bidang keahlian yang dipilih. Sedangkan $43 \%$ memiliki potensi yang tidak sesuai dengan bidang keahlian. Apabila hal ini dibiarkan, maka terkait dengan penguasaan kompetensi keahlian harus benar-benar mendapat pembinaan yang baik dari semua pihak baik guru, wali, konselor dan orang tua siswa. Apabila penguasaan kompetensi tidak bagus, maka lulusan vokasi akan tidak terserap dengan baik di dunia kerja. Apabila dilihat secara 
lebih detail lagi, dari 57\% yang dianggap akan berpotensi ke depannya, hanya sebesar $3 \%$ sangat kompeten, $12 \%$ kompeten, $42 \%$ cukup kompeten. Dalam menghadapi revolusi industri 4.0 diperlukan sumber daya manusia unggul dan kompeten, maka disinilah diperlukan perhatian baik dari

$$
\begin{aligned}
& \hline \equiv \\
& \text { Data } \\
& \hline 10 \\
& \hline 10 \\
& \hline 222 \\
& 18 \\
& \hline 18 \\
& 20 \\
& 20 \\
& \hline 20 \\
& 20 \\
& 20 \\
& 20 \\
& \hline
\end{aligned}
$$

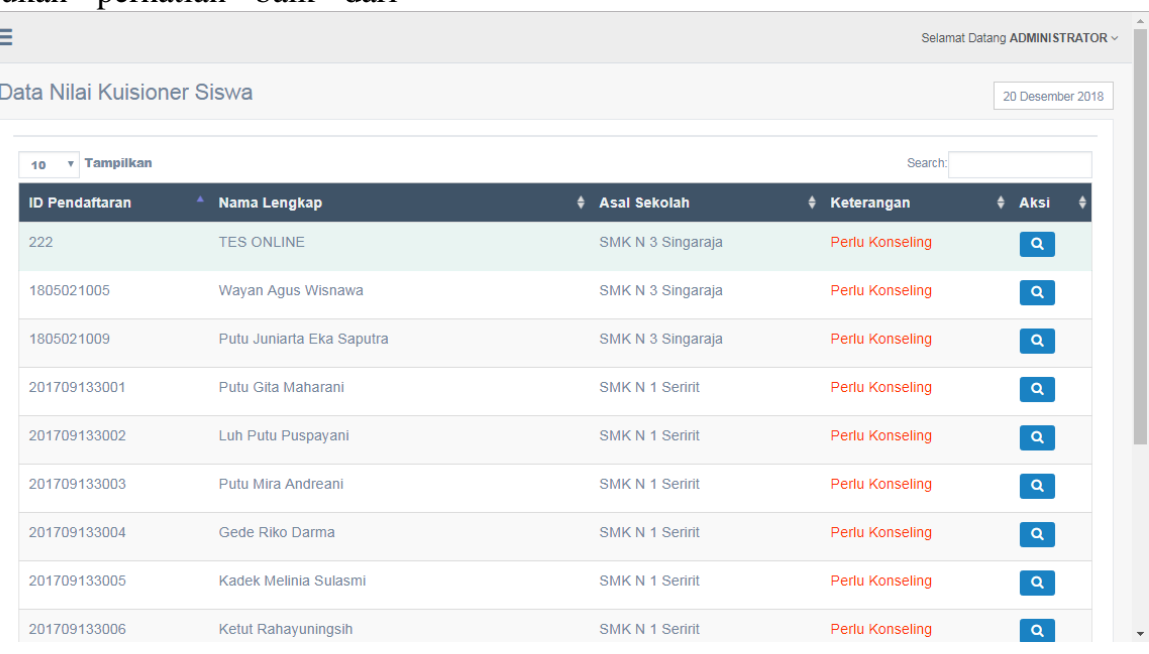

Gambar 3. Hasil Tes Siswa
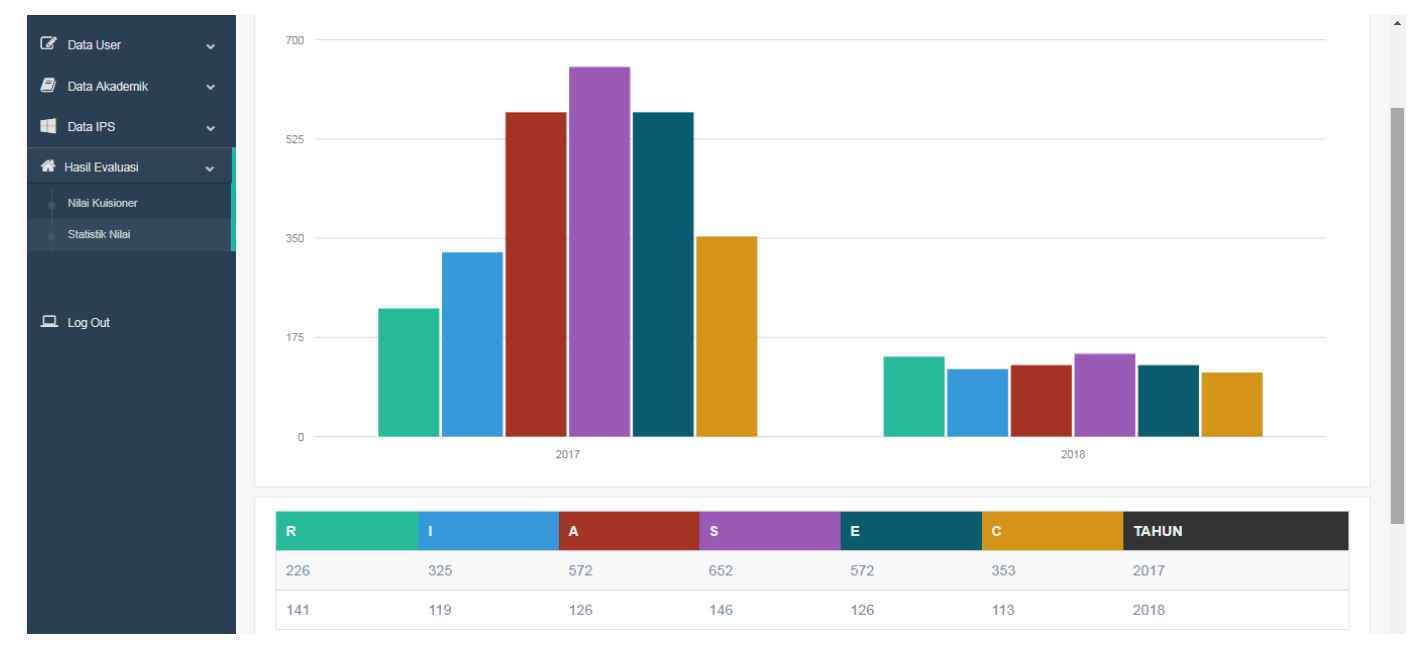

Gambar 4. Grafik Kompetensi per Tahun

\section{SIMPULAN}

SDM yang unggul di masa depan adalah yang memiliki karakter kuat dan kreatif dalam menghadapi segala persoalan dalam rangka menghadapi persaingan kerja yang semakin ketat. Proses pembentukan SDM seperti itu membutuhkan treatment khusus, karena sekolah vokasi juga sekolah khusus untuk mencetak insan yang memiliki skill tertentu untuk keperluan di bidang tertentu. Proses belajar akan baik apabila siswa merasa senang dan mampu untuk mengikuti pemerintah, sekolah, industri, dan masyarakat untuk berdiskusi dan mencari solusi untuk lulusan vokasi yang semakin kompetitif. Hasil tes dapat dilihat seperti pada Gambar 3 dan Grafik per tahun seperti Gambar 4. 
Proses bimbingan di sekolah diharapkan mampu mendorong kesuksesan belajar di sekolah melalui peran guru, orang tua, institusi, dan dunia industri untuk memperkecil jumlah pengangguran saat lulus nanti.

\section{DAFTAR PUSTAKA}

[1] Alfindasari, Dessy. 2014. Langkahlangkah Melakukan R\&D (Research and Development), http://www.eurekapendidikan.com/ 2014/12/karakteristik-r-research-a nd-development.html, Diakses (28 Oktober 2016)

[2] Asmara, Andik dan Haryanto. 2015. Pengembangan Tes Minat Dan Bakat Dengan Metode Jaringan Syaraf Tiruan (JST) untuk Memprediksi Potensi Siswa Bidang Robotika, Jurnal Pendidikan Vokasi, Vol 5, Nomor 3, Hal. 273286, November 2015

[3] Bassil, Youssef. 2012. A Simulation Model for the Waterfall Software Development Life Cycle.International Journal of Engineering \& Technology (IJET), Vol. 2, No 5

[4] Deha, S. dan Mulyana, R.R, 2010, Studi Implementasi Evaluasi Berbasis Kompetensi (Studi Kasus pada SMKN 6 Bidang Keahlian Teknik Bangunan), Peran LPTK Dalam Pengembangan Pendidikan Vokasi di Indonesia, Seminar Nasional dan Internasional, Aptekindo, ISSN 1907-2066

[5] Hanafi, Ivan, 2014. Pendidikan Teknik dan Vokasional. Bandung: PT Refika Aditama.

[6] Hanafi, Ivan. 2012. Re-Orientasi Keterampilan Kerja Lulusan Pendidikan Kejuruan. Jurnal Pendidikan Vokasi, 2 (1): 107116

[7] Hartono, Jogiyanto, 2005. Analisis \& Desain Sistem Informasi: pendekatan terstruktur teori dan praktik aplikasi bisnis. Yogyakarta : Penerbit Andi.

[8] Holland, J. L. 1975.Manual for the Vocational Preference Inventory. Palo Alto, CA: Consulting Psychologists Press.
[9] Holland, J., 1985, Making Uccupation Choise, Prentice-Hall, New Jersey

[10]Humas, 2016. Mayoritas Pengangguran Lulusan SMK, Presiden Jokowi Minta Sistem Pendidikan Vokasi Dirombak, http://setkab.go.id/category/berita/ , (diakses : 28 Oktober 2016)

[11] Jampel, I.N, PEMBENTUKAN

KARAKTER UNTUK MEMPERKUAT SUMBER DAYA MANUSIA YANG INOVATIF, Seminar Nasional Vokasi dan Teknologi (SEMNASVOKTEK), ISSN Cetak : 2541-2361

[12] Jatmoko, Dwi. 2013. Jurnal Pendidikan Vokasi, Vol 3, Nomor 1, Februari 2013

[13] Miller, Springer, Tobacyk \& Wells. 2004. Congruency Between SDS

Personality Type and Environmental Model. College Student Journal. (online). v.8, n.6073197, pg.2. (http://findarticles.com/p/articles/m i_mOFCR/is_1_38/ai_n6073197/pg 2), Diakses 24 Juli 2008.

[14] Nauta, M.M. 2010. The Development, Evolution, and Status of Holland's Theory of Vocational Personalities: Reflections and Future Directions for Counseling Psychology. Journal of Counseling Psychology, 57 (11),pp. 11-22. DOI: $10.1037 / \mathrm{a} 0018213$.

[15] Nazzaro, Antonio, 2016. The Italian national plan for digital school in the framework of the Digital Agenda for Europe, ttp://s3.amazonaws.com/academia. edu.documents/33373326/NAZZAR O_DUBAI_INVIO.pdf? AWSAccessKeyId =AKIAJ56TQJRT WSMTNPEA\&Expires $=147764895$ $4 \&$ Signature $=l C m V Z P v X W \% 2 B 6 k$ HvXiJBG67mrNLhw\%3D\&respons $e$-contentdisposition=attachment $\% 3 \mathrm{~B} \% 20 \mathrm{fil}$ ename \%3DThe_Italian_national_plan_fo r_digital_sc.pdf , (diakses: 28 Oktober 2016)

[16] Permana, A.A.J., 2013. Sistem Cerdas Evaluasi Kelayakan Mahasiswa Magang Menggunakan Elman Recurrent Neural Network 
(ERNN) (Studi Kasus : Jurusan Manajemen Informatika, Fakultas Teknik dan Kejuruan, Universitas Pendidikan Ganesha, Singaraja-Bali ), Tesis, Program Studi Pasca Sarjana Ilmu Komputer, Jurusan Ilmu Komputer dan Elektronika, FMIPA, UGM, Yogyakarta

[17] Pratiwi, Y.R, 2013. Efektivitas Sekolah Menengah Kejuruan Berstandar ISO 9001:2008 terhadap Pencapaian Standar Isi, Standar Proses dan Standar Kompetensi Lulusan, Jurnal Pendidikan Sains, Volume 1, Nomor 3, September 2013, Halaman 217-227

[18]Rencana Strategis (Renstra) Kementerian Pendidikan dan Kebudayaan Tahun 2010-2014 disusun berdasarkan UU No. 20 Tahun 2003 tentang Sistem Pendidikan Nasional

[19] Sunardi, Purnomo, Sutadji.E. 2016. PENGEMBANGAN

EMPLOYABILITY SKILLS

SISWA SMK DITINJAU DARI IMPLEMENTASI PENDEKATAN SAINTIFIK, Jurnal Pendidikan, Vol. 1, No. 7, Bln Juli, Thn 2016, Hal 1391-1398

[20] Suranata, K., 2009, Hubungan Antara Kesesuaian Tipe Kepribadian dan Model Lingkungan dengan Kematangan Arah Pilihan Karier (Studi pada Siswa Kelas XII di SMK N 1 Padang), Tesis, Program Studi Bimbingan dan Konseling, Program Pascasarjana, Universitas Negeri Padang, Padang. 2016. http://vokasi.ub.ac.id/tentang-vokas i/, Diakses (28 Oktober 2016)

[21] Triyono, M.B, 2017. TANTANGAN REVOLUSI INDUSTRI KE 4 (i4.0) BAGI PENDIDIKAN VOKASI, Seminar Nasional Vokasi dan Teknologi (SEMNASVOKTEK), ISSN Cetak : 2541-2361 | ISSN Online : 25413058, Denpasar-Bali, 28 Oktober 2017

[22] Universitas Brawijaya. 2016. http://vokasi.ub.ac.id/tentang-vokas i/, Diakses (28 Oktober 2016)

[23] UU No. 12, 2012. Undang-Undang Republik Indonesia Nomor 12 Tahun 2012 Tentang Pendidikan Tinggi, Republik Indonesia
[24] Undang-undang Republik Indonesia No. 20 tahun 2003 tentang sistem pendidikan nasional 